\title{
THE REVERSE DIALYSIS BAG METHOD FOR THE ASSESSMENT OF IN VITRO DRUG RELEASE FROM PARENTERAL NANOEMULSIONS - A CASE STUDY OF RISPERIDONE
}

Nebojša D. Cekić ${ }^{1,2^{*}}$, Sanela M. Savić ${ }^{1}$, Tanja M. Ilićn ${ }^{3}$ Snežana D. Savić 3

${ }^{1}$ DCP Hemigal, Leskovac, Serbia

2Faculty of Technology, University of Niš, Leskovac, Serbia

${ }^{3}$ Department of Pharmaceutical Technology and Cosmetology, Faculty of Pharmacy, University of Belgrade, Belgrade, Serbia

The present study describes the release pattern of risperidone, a poorly water-soluble psychopharmacological drug, from two parenteral nanoemulsions containing the mixture of medium-chain triglycerides and soybean oil as an oil phase, sodium oleate solution as an aqueous phase and lecithin alone or in combination with polysorbate 80 as emulsifiers/stabilizers. The nanoemulsions were prepared by hot highpressure homogenization, and evaluated regarding physicochemical properties - a droplet size, polydispersity index, zeta potential, and viscosity, as well as biopharmaceutical performances - in vitro drug release by employing a reverse dialysis bag technique.Physicochemical characterization revealed a favorable mean droplet size $(160-210 \mathrm{~nm})$, narrow size distribution $(<0.15)$, high surface charge (around $-50 \mathrm{mV}$ to $-60 \mathrm{mV}$ ) and low apparent viscosity (4-6 mPa.s) of developed nanoemulsions, thus proving their suitability for parenteral administration of poorly water-soluble actives. The in vitro drug release study showed biphasic release profiles of risperidone, with significant differences between two investigated nanoemulsion formulations (differing only in the presence of polysorbate 80 ), indicating the influence of nanoemulsion matrix on drug release kinetics. However, the release of risperidone from investigated nanoemulsions was relatively rapid (more than $50 \%$ released within the first $5 \mathrm{~min}$ ), suggesting their promising application in emergency situations. Furthermore, above $95 \%$ of the drug was released from both tested nanoemulsions within 180 min, while the kinetic release process could be described by Korsmeyer-Peppas model and supposed to be diffusion-controlled.Overall, it can be concluded that the reverse dialysis bag technique was the appropriate and enough discriminatory method to evaluate the in vitro release of risperidone from presented nanoemulsion systems.
(ORIGINAL SCIENTIFIC PAPER) UDC 615.214.2.015:66.09

Keywords: nanoemulsions, risperidone, release testing, dialysis method, release profile, mathematical modeling

\section{Introduction}

Considering numerous appealing features including biocompatibility, biodegradability, physical stability, the possibility of sterilization and scale up and especially the high solubilization capacity of lipophilic drugs, the improved penetration through biological barriers, possibly enhanced bioavailability, controlled drug release and organ targeting, the increasing attention has been focused more recently on nanoemulsions as promising drug carriers for different routes of administration, especially for the parenteral application $[1,2]$. Although lipid nanoemulsions have been traditionally employed for parenteral nutrition, and some have been clinically approved for the intravenous delivery of lipophilic drugs (e.g., diazepam, propofol, etomidate) [3,4], (i) high quality and safety requirements imposed by the parenteral route of administration, (ii) specific characteristics of drug substances (poor water-solubility, significant first-pass metabolism, nonspecific biodistribution, P-glycoprotein efflux), (iii) the influence of various factors (formulation parameters, processing variables, the presence of the model drug) on the physicochemical properties and stability of nanoemulsions, and (iv) the influence of the nanoemulsion system on its own on the behavior of the incorporated drug (the release form nanoemulsion, pharmacokinetic performances and consequently, a therapeutic effect), make the development of parenteral nanoemulsions a complicated and challenging task, and additional efforts are required in order to optimize the nanoemulsion formulation, stability, drug delivery and overall in vivo behavior [1-4].

Verily, an issue of particular importance to be considered in the design of parenteral nanoemulsions as colloidal drug carriers is the characterization of the in vitro drug release from the developed carrier; the data obtained from the in vitro release test can be used to evaluate and demonstrate the product performance/quality in both drug development and quality control settings, to elucidate the structure and release mechanisms/kinetics and, ideally, to predict the in

\footnotetext{
*Author address: Nebojša Cekić, DCP Hemigal, Tekstilna 97, 16000 Leskovac, Serbia / Nebojša Cekić, Faculty of Technology, University of Niš, Bulevar oslobođenja 124, 16000 Leskovac, Serbia

E-mail: nesafarm@gmail.com

The manuscript received: December, 06, 2019.

Paper accepted: January, 13, 2020.
} 
vivo behavior of the system. Accordingly, comprehending the factors that can influence the drug release from nanoemulsions from both in vitro and in vivo aspect, is essential for the development of relevant in vitro release tests and the definition of the quality/performance specifications [59]. The study of in vitro drug release from nanoemulsion formulations (and nanoparticulate systems in general) is technically quite demanding because of: (i) the physical obstacles associated with the separation of the released drug from the carrier in an effective and time-efficient manner, (ii) the extremely small size of dispersed oil droplets and, therefore a large surface area compared to their volume, which can lead to the rapid drug transport from the oil to the continuous phase and (iii) the potential for violation of the sink conditions $[6,10,11]$. Furthermore, unlike oral and transdermal dosage forms, for parenteral preparations involving lipid emulsions there is currently no standard, pharmacopoeial nor any other regulatory approved/suggested method for the in vitro drug release kinetics examination $[7-9,12]$. So far, the methods that have been used for that purpose, with more or less success include: (i) sampleand-separate methods (ultrafiltration, ultracentrifugation, centrifugal ultrafiltration) [13-15], (ii) in situ methods [16,17], (iii) continuous flow-through methods (USP apparatus 4, with dialysis adapter) [18-22], and (iv) membrane diffusion/ barrier methods (side-by-side diffusion cell method, dialysis sac/bag method) [11,21,23-29], each with its own advantages and disadvantages $[5,6,11,12]$.

In order to avoid the separation problem and overcome the drawbacks of conventional barrier methods (such as rate-limiting properties of the membrane and violation of the sink conditions), the bulk equilibrium reverse dialysis bag technique was developed $[10,11,24]$, in which the release medium placed inside the dialysis bags represents the receiver phase, while the investigated nanoemulsion dispersed into the release medium surrounding the dialysis bags represents the donor phase. In that way, the maximum (theoretically infinite) dilution of nanoemulsion upon its immersion in the release medium (sink solution, donor phase) is achieved, and the drug release is believed to be performed under perfect sink conditions. The additional advantage of the said method is the exposure of the high free surface area of nanoemulsion droplets to the high volume of the sink solution, thus mimicking in vivo situation for nanoemulsions and other colloidal systems administered parenterally $[10,11]$.

Taking all this into account, the present study was aimed at assessing the pertinence of the reverse dialysis bag method for the study of in vitro drug release from parenteral nanoemulsions and at evaluating its potential to distinguish between different nanoemulsion formulations. For this purpose, two drug-loaded nanoemulsions containing the mixture of medium-chain triglycerides and the soybean oil as the oil phase, and the sodium oleate solution as the aqueous phase, and stabilized by lecithin-polysorbate 80 mixture or lecithin alone $[30,31]$ were prepared by hot highpressure homogenization and characterized regarding their physicochemical properties and in vitro drug release.
Risperidone (RSP), a well-recognized and clinically proved atypical antipsychotic drug, was incorporated into nanoemulsion droplets as a poorly water-soluble model compound (molecular weight: 410.48; solubility (in unbuffered water pH 8.78, $25^{\circ} \mathrm{C}$ ): $0.014 \mathrm{~g} / \mathrm{L}$; pKa (most basic, $25^{\circ} \mathrm{C}$ ): $8.07 \pm 0.1 ; \log \mathrm{P}\left(25^{\circ} \mathrm{C}\right): 2.678 \pm 0.406$ [32]). By analyzing the obtained release profiles of developed RSP-loaded nanoemulsions through employing several mathematical models, the aim was to determine whether nanoemulsion composition, particularly the emulsifier type, affected drug release kinetics, which further may have consequences on in vivo effects.

\section{Experimental}

\section{Materials}

The ingredients used for the preparation of drug-loaded and corresponding unloaded nanoemulsions, including the manufacturers/suppliers of the said ingredients are given in Table 1. Ultra-pure water was obtained with a GenPure apparatus (TKA Wasseranfbereitungssysteme $\mathrm{GmbH}$, Germany). Sodium hydroxide, potassium phosphate monobasic, and methanol (used for in vitro dialysis and spectrophotometric analysis) were purchased from SigmaAldrich Chemie GmbH (Germany). All chemicals and reagents were of pharmaceutical or HPLC grade, and used as received without further purification.

\section{Preparation of nanoemulsions}

Nanoemulsions were prepared by hot high-pressure homogenization $\left(50^{\circ} \mathrm{C}\right.$ ) according to the previously reported procedure $[30,31]$. Briefly, the oil phase, comprising medium-chain triglycerides, soybean oil, soybean lecithin and butylhydroxytoluene was heated under slight magnetic stirring until lecithin was completely dissolved, and then a RSP solution in benzyl alcohol was added. The prepared oil phase $\left(50^{\circ} \mathrm{C}\right)$ was combined with the separately prepared aqueous phase $\left(50^{\circ} \mathrm{C}\right)$ consisting of ultra-pure water, polysorbate 80 , sodium oleate and glycerol, and further pre-homogenized (10,000 rpm, $3 \mathrm{~min}$ ) with a rotor-stator homogenizer (IKA Ultra-Turrax® T25 digital, IKA®-Werke GmbH \& Co. KG, Germany). The obtained coarse emulsion was subsequently homogenized with a high-pressure homogenizer (Emulsi-Flex-C3, Avestin Inc., Canada) at 500 bar for 10 repeated cycles. The resulting nanoemulsion was aseptically filtered through the $0.22 \mu \mathrm{m}$ membrane filter and poured into crimped glass vials. Blank nanoemulsions (P-IpNE and P-INE as placebo formulations for RSP-IpNe and RSP-INE, respectively) were also prepared according to the above described procedure without RSP. All formulations were stored at $25 \pm 2{ }^{\circ} \mathrm{C}$ and after $24 \mathrm{~h}$, their characterization was performed. All measurements were done in triplicate. Code names and the composition of developed RSP-loaded nanoemulsions are given in Table 1. 
Table 1. Composition of risperidone-loaded nanoemulsion formulations

\begin{tabular}{|c|c|c|c|c|}
\hline \multirow{2}{*}{$\begin{array}{l}\text { Ingredients } \\
(\% \mathrm{w} / \mathrm{w})\end{array}$} & \multirow[t]{2}{*}{ Manufacturer/Supplier } & \multirow[t]{2}{*}{ Function } & \multicolumn{2}{|c|}{$\begin{array}{l}\text { Nanoemulsion } \\
\text { formulation }\end{array}$} \\
\hline & & & RSP-IpNE & RSP-INE \\
\hline Risperidone & Zdravlje Actavis, Serbia & $\begin{array}{l}\text { Active } \\
\text { substance, } \\
\text { antipsychotic }\end{array}$ & 0.1 & 0.1 \\
\hline $\begin{array}{l}\text { Medium-chain } \\
\text { triglycerides }\end{array}$ & $\begin{array}{l}\text { Fagron GmbH \& KG, } \\
\text { Germany }\end{array}$ & Constituent & 16.0 & 16.0 \\
\hline $\begin{array}{l}\text { Soybean oil } \\
\text { (Lipoid Purified } \\
\text { Soybean Oil 700) }\end{array}$ & Lipoid GmbH, Germany & Constituent & 4.0 & 4.0 \\
\hline $\begin{array}{l}\text { Soybean lecithin } \\
\text { (Lipoid S 75) }\end{array}$ & Lipoid GmbH, Germany & $\begin{array}{l}\text { Emulsifier } \\
\text { (lipophilic) }\end{array}$ & 2.0 & 2.0 \\
\hline Butylhydroxytoluene & Sigma-Aldrich Co., USA & Antioxidant & 0.05 & 0.05 \\
\hline Benzyl alcohol & Sigma-Aldrich Co., USA & Cosolvent & 2.0 & 2.0 \\
\hline Polysorbate 80 & Sigma-Aldrich Co., USA & $\begin{array}{l}\text { Emulsifier } \\
\text { (hydrophilic) }\end{array}$ & 2.0 & - \\
\hline $\begin{array}{l}\text { Sodium oleate } \\
\text { (Lipoid Sodium } \\
\text { Oleate B) }\end{array}$ & Lipoid GmbH, Germany & $\begin{array}{l}\text { Buffering } \\
\text { agent }(\mathrm{pH} 9) \\
\text { co-stabilizer }\end{array}$ & 0.03 & 0.03 \\
\hline Glycerol & Merck KGaA, Germany & Isotonic agent & 2.25 & 2.25 \\
\hline Ultra-pure water, to & $\begin{array}{l}\text { University of Belgrade - } \\
\text { Faculty of Pharmacy, Serbia }\end{array}$ & Constituent & 100.0 & 100.0 \\
\hline
\end{tabular}

\section{Nanoemulsion characterization}

Droplet size and size distribution analysis

The mean droplet size (intensity weighted mean diameter, Z-average diameter, Z-Ave) and the droplet size distribution (polydispersity index, PDI) of nanoemulsions (previously diluted with ultra-pure water at 1:500, v/v) were determined by photon correlation spectroscopy, using a Zetasizer Nano ZS90 (Malvern Instruments Ltd., UK). The measurements were done at $25{ }^{\circ} \mathrm{C}$, at a fixed scattering angle of $90^{\circ}$, using a He-Ne laser at $633 \mathrm{~nm}$.

\section{Zeta potential analysis}

The droplet surface charge of nanoemulsions was determined with a Zetasizer Nano ZS90 (Malvern Instruments Ltd.) by measuring the electrophoretic mobility of nanoemulsion droplets, which was converted to the zeta potential $(Z P)$ using the in-built software. The measurements were performed at $25{ }^{\circ} \mathrm{C}$ immediately upon dilution of nanoemulsion samples $(1: 500, \mathrm{v} / \mathrm{v})$ with ultrapure water, having constant conductivity (about $50 \mu \mathrm{S}$ / $\mathrm{cm}$ ) adjusted by the $0.1 \mathrm{M}$ phosphate buffer solution.

\section{Rheological analysis}

The rheological behavior of nanoemulsions was assessed using a Visco Elite-R rotational viscometer (Fungilab S.A., Spain), equipped with the low viscosity adapter (LCP) and controlled by Supervisc software (Fungilab S.A.). The measurements were performed at $20^{\circ} \mathrm{C}$ within the speed range $100-200 \mathrm{rpm}$.

\section{In vitro drug release study from nanoemulsions}

In vitro release profile of RSP-loaded parenteral nanoemulsions was examined using the bulk equilibrium reverse dialysis bag technique, previously described by Benita and Levy (1993) [10] and Chidambaram and Burgess (1999) [11]. Dialysis bags (cellulose membrane, molecular weight cut-off 12 kDa, Sigma-Aldrich, Germany), containing $5 \mathrm{~mL}$ of the release medium (acceptor phase) were placed into a vessel containing $300 \mathrm{~mL}$ of the same release medium in which, after proper equili- bration, $3 \mathrm{~mL}$ of the investigated RSP nanoemulsion was added (donor phase). As release medium, the mixture of the phosphate buffer solution ( $\mathrm{pH} 7.4$, USP) and metha$\mathrm{nol}$ at the ratio of 80:20 (v/v) was used, and the release studies were performed at the temperature of $37 \pm 1{ }^{\circ} \mathrm{C}$, under constant stirring (ES-20 orbital shaker-incubator, Biosan SIA., Latvia), to simulate the in vivo conditions. At specified time intervals $(5,15,30,60,90$, and $180 \mathrm{~min})$, the content of the dialysis bag and the same volume of the surrounding medium were sampled and assayed spectrophotometrically for the RSP concentration using Evolution 300 UV-Vis spectrophotometer (Thermo Fisher Scientific, USA) at $277 \mathrm{~nm}$. The calibration curve was linear in the range from 5 to $35 \mu \mathrm{g} / \mathrm{mL}\left(R^{2}=0.9942\right)$. The RSP release kinetics from the tested nanoemulsions was evaluated by fitting the experimental data obtained from the release assay through several mathematical models (zero order, first order, Higuchi, Hixson-Crowell, Baker-Lonsdale, Korsmeyer-Peppas, Weibull), by employing DDSolver add-in program for the Microsoft Excel application.

\section{Statistical analysis}

The results of nanoemulsion physicochemical characterization, presented as mean parameter value \pm standard deviation ( $n=3$ ), were statistically compared using Student's t-test (PASW Statistics v.18.0; SPSS Inc., USA), whereas the results of the in vitro release study of RSP from the investigated nanoemulsions, i.e., drug release profiles, were compared by univariate analysis of variance (ANOVA). The $p$ value of 0.05 was taken as the level of significance.

\section{Results and Discussion}

In comparison with the previous research [30,31], in this paper the two most promising nanoemulsion formulations intended for parenteral use, differing only in the presence of polysorbate 80 as co-emulsifier, with RSP as a model drug (RSP-IpNE, RSP-INE, Table 1) have been prepared, and their physicochemical properties, and for the first time biopharmaceutical performances have been reported. The results of the measured physicochemical parameters (Z-Ave, PDI, ZP, apparent viscosity) for formulated RSP-loaded nanoemulsions (RSP-IpNE, RSP-INE), together with their corresponding unloaded formulations (P-IpNE, P-INE) one day after the preparation are displayed in Figure 1. All prepared nanoemulsions were free-flowing, milky-white, homogeneous and, as Figure 1 shows, with a small mean droplet size $(156-216 \mathrm{~nm})$, narrow size distribution (0.09 -0.15 ), high negative surface charge (from -41 to -62 $\mathrm{mV})$, and low apparent viscosity ( $3-12 \mathrm{mPa} . \mathrm{s})$, thus proving their suitability for parenteral administration and delivery of poorly water-soluble drugs. As discussed in detail earlier [31], the incorporation of RSP did not significantly change the nanoemulsion droplet size, size distribution and surface charge (Figure 1), suggesting 
that the drug might have been localized predominantly in the oil core of the nanoemulsion, whereas the significantly ( $p<0.05$, t-test) lower viscosity of nanoemulsions upon RSP loading (Figure 1) might be related to the putative presence of a portion of drug molecules in the oil/ water interface, as well. In addition, when comparing the nanoemulsion stabilized by lecithin-polysorbate $80 \mathrm{mix}-$ ture (RSP-IpNE) with the co-emulsifier-free formulation (RSP-INE), it could be seen that polysorbate 80 -costabilized nanoemulsion had a significantly $(p<0.05, t$-test) smaller mean droplet size (RSP-IpNE: $160 \pm 2 \mathrm{~nm}$ vs. RSP-INE: $208 \pm 2 \mathrm{~nm}$, Figure 1), which could explain the eventual difference in RSP release profiles from developed nanoemulsion formulations.

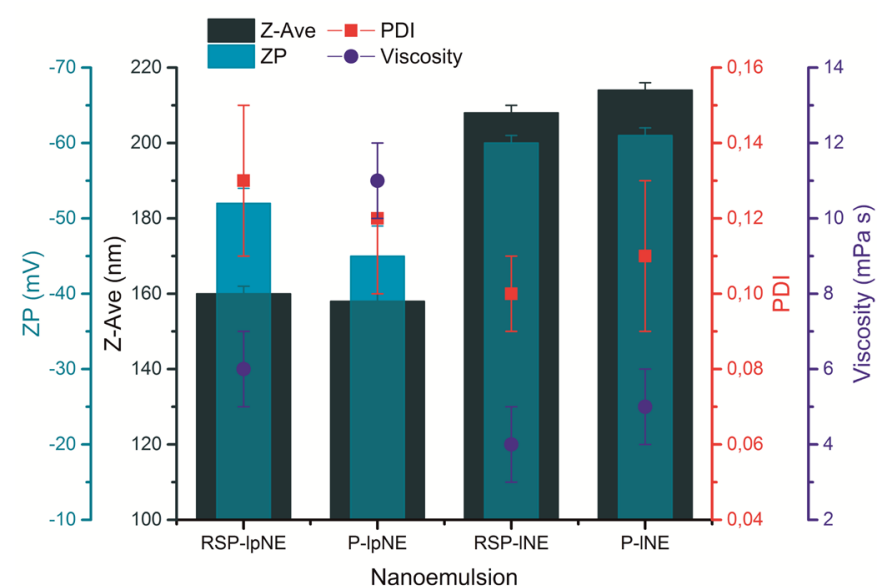

Figure 1. Representative physicochemical characteristics of the developed parenteral risperidone-loaded (RSP-IpNE, RSP-INE) and corresponding unloaded (P-IpNE, P-INE) nanoemulsions, one day after the preparation (mean \pm standard deviation, $n=3$ ); Z-Ave, mean droplet size; PDI, polydispersity index; ZP, zeta potential.

The main focus of the present study was the characterization of release kinetics/profiles of RSP, as a BCS (Biopharmaceutics Classification System) class II model drug (low solubility, high permeability) [33], incorporated into two parenteral nanoemulsions, stabilized by lecithin, where one of them was co-stabilized with polysorbate 80 . For that purpose, the formulated RSP-loaded nanoemulsions were subjected to the reverse dialysis bag technique as the mainly recommended method, besides the standardized flow-through cell (USP apparatus 4) with the appropriate modification (dialysis adapter), for studying the in vitro drug release kinetics from nanoemulsion carriers [8]. The fraction (\%) of the released drug from the investigated parenteral nanoemulsions was calculated as the ratio of the RSP concentration measured at specified time intervals in the medium inside the dialysis bags (acceptor phase), and the total drug concentration in the outside medium (diluted nanoemulsion), i.e., the sink solution (donor phase) [24] and the obtained RSP release profiles with the schematic representation of the reverse dialysis bag method are presented in Figure 2.

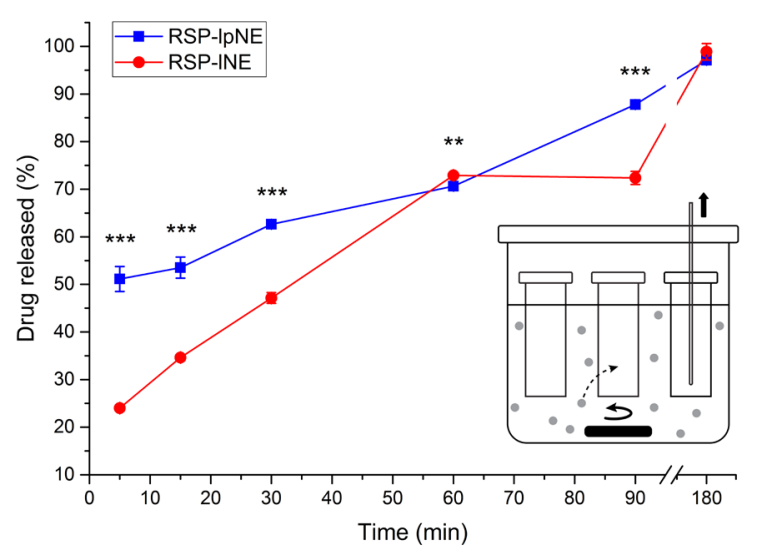

Figure 2. Drug release profiles of risperidone from the investigated parenteral nanoemulsions (mean \pm standard deviation, $n$ $=3$ ), with the schematic representation of the reverse dialysis bag technique; ${ }^{* *} p<0.01,{ }^{* * *} p<0.001$.

As it can be seen from Figure 2, the in vitro release of RSP from both parenteral nanoemulsions, RSP-IpNE and RSP-INE, was characterized by biphasic profile, with the initial rapid release (possibly due to the diffusion of free drug or drug solubilized into micelles from the donor phase to the acceptor medium), followed by a slower release in the later time points (probably due to the release of the drug from nanoemulsion oil droplets to the continuous donor phase, and then its diffusion through a dialysis membrane into the acceptor medium) [11]. In undiluted nanoemulsion, in the equilibrium state, the drug substance is distributed between dispersed oil droplets, a continuous aqueous phase, and micelles presented in the aqueous phase of nanoemulsion [23]. Upon nanoemulsion dilution with the release medium, a new equilibrium is established, and the drug substance is distributed between nanoemulsion oil droplets and medium (sink solution), which now becomes the outer phase of nanoemulsion. The drug released from the oil nanodroplets diffuses into the sink solution, and then through the membrane into the dialysis bag until the equilibrium is reached, whereby it is noticed that the concentration of the drug in the dialysis bag increases, while the concentration in the sink solution remains almost unchanged [24]. Similar findings were reported earlier with several other drugs incorporated into parenteral nanoemulsions such as diazepam [24,34], benzocaine [11], benzathine penicillin G [25]; thalidomide [26], nystatin [29], to mention a few.

When comparing the obtained RSP release profiles (Figure 2), the significant difference could be found between the two tested nanoemulsions, RSP-IpNE and RSP-INE, differing only in the presence of polysorbate 80 as co-emulsifier, indicating the influence of nanoemulsion matrix on the drug release kinetics. The initial rapid release was particularly pronounced in case of RSP-IpNE formulation stabilized by lecithin-polysorbate 80 mixture, from which more than $50 \%$ of the drug was released within the first $5 \mathrm{~min}$. Furthermore, the fraction 
of the released RSP from this nanoemulsion was significantly higher ( $t$-test, $p<0.05)$ compared to the RSPINE formulation, in almost all time points except for 60 min and 180 min (Figure 2). On the other hand, in case of RSP-INE nanoemulsion stabilized by lecithin only, after the initial slower release, the increase in the fraction of the drug released could be observed with time, and within one hour from the beginning of the experiment it approached the value of RSP fraction released from comparative RSP-IpNE nanoemulsion (Figure 2). Finally, after $180 \mathrm{~min}$, the overall percentage of the released RSP was almost identical for both tested nanoemulsions, irrespective of the presence of co-emulsifier/co-stabilizer, and reached almost 100\% (RSP-IpNE: $97.1 \% \pm 0.5 \%$; RSP-INE: $98.9 \% \pm 1.7 \%$ ).

Table 2. In vitro release kinetic data of risperidone from the investigated parenteral nanoemulsions

\begin{tabular}{|c|c|c|c|c|}
\hline \multirow[t]{2}{*}{ Kinetic model } & \multirow[t]{2}{*}{ Equation } & \multirow[t]{2}{*}{ Parameter } & \multicolumn{2}{|c|}{$\begin{array}{c}\text { Nanoemulsion } \\
\text { formulation }\end{array}$} \\
\hline & & & RSP-IpNE & RSP-INE \\
\hline Zero-order & $F=k_{0} \times t$ & $\begin{array}{c}\mathrm{k}_{0} \\
\mathrm{R}^{2} \\
\mathrm{R}_{\text {adusted }}^{2} \\
\mathrm{AlC}\end{array}$ & $\begin{array}{c}0.719 \\
-3.6972 \\
-3.6972 \\
56.00\end{array}$ & $\begin{array}{c}0.679 \\
0.1204 \\
0.1204 \\
50.87\end{array}$ \\
\hline First-order & $F=100 \times\left(1-e^{-k_{1} \times t}\right)$ & $\begin{array}{c}\mathrm{k}_{1} \\
\mathrm{R}^{2} \\
\mathrm{R}_{\text {acjusted }}^{2} \\
\mathrm{AlC}\end{array}$ & $\begin{array}{c}0.041 \\
-0.0002 \\
-0.0002 \\
46.71\end{array}$ & $\begin{array}{c}0.021 \\
0.8936 \\
0.8936 \\
38.19\end{array}$ \\
\hline Higuchi & $F=k_{H} \times t^{0.5}$ & $\begin{array}{c}\mathrm{k}_{\mathrm{H}} \\
\mathrm{R}^{2} \\
\mathrm{R}_{\text {acjusted }}^{2} \\
\mathrm{AlC}\end{array}$ & $\begin{array}{c}8.809 \\
-0.1881 \\
-0.1881 \\
47.73\end{array}$ & $\begin{array}{c}7.957 \\
0.9313 \\
0.9313 \\
35.55\end{array}$ \\
\hline Hixson-Crowell & $F=100 \times\left\lfloor 1-\left(1-k_{H C} \times t\right)^{3}\right\rfloor$ & $\begin{array}{c}\mathrm{k}_{\mathrm{HC}} \\
\mathrm{R}^{2} \\
\mathrm{R}_{\text {aciusted }}^{2} \\
\mathrm{AlC}\end{array}$ & $\begin{array}{c}0.008 \\
-0.4746 \\
-0.4746 \\
49.03\end{array}$ & $\begin{array}{c}0.006 \\
0.8342 \\
0.8342 \\
40.86\end{array}$ \\
\hline Baker-Lonsdale & $\frac{3}{2} \times\left[1-\left(1-\frac{F}{100}\right)^{\frac{2}{3}}\right]-\frac{F}{100}=k_{B L} \times t$ & $\begin{array}{c}\mathrm{k}_{\mathrm{BL}} \\
\mathrm{R}^{2} \\
\mathrm{R}_{\text {aciusted }}^{2} \\
\mathrm{AlC}^{2}\end{array}$ & $\begin{array}{c}0.003 \\
0.5720 \\
0.5720 \\
41.53\end{array}$ & $\begin{array}{c}0.002 \\
0.9729 \\
0.9729 \\
29.75\end{array}$ \\
\hline Korsmeyer-Peppas & $F=k_{K P} \times t^{n}$ & $\begin{array}{c}k_{\mathrm{KP}} \\
n \\
\mathrm{R}^{2} \\
\mathrm{R}_{\text {acjusted }}^{2} \\
\text { AlC }\end{array}$ & $\begin{array}{l}32.079 \\
0.211 \\
0.9322 \\
0.9153 \\
32.46\end{array}$ & $\begin{array}{c}12.718 \\
0.397 \\
0.9753 \\
0.9692 \\
31.43\end{array}$ \\
\hline Weibull & $F=100 \times\left(1-e^{\frac{-\left(t-T_{t}\right)^{\beta}}{\alpha}}\right)$ & $\begin{array}{c}\alpha \\
\beta \\
\beta \\
\mathrm{T}_{i} \\
\mathrm{R}^{2} \\
\mathrm{R}_{\text {aciustod }}^{2} \\
\text { AlC }\end{array}$ & $\begin{array}{c}153637.49 \\
8 \\
2.275 \\
-151.699 \\
0.9792 \\
0.9653 \\
27.41\end{array}$ & $\begin{array}{c}80.011 \\
\\
1.024 \\
-13.984 \\
0.9745 \\
0.9575 \\
33.41\end{array}$ \\
\hline $\begin{array}{l}F \text {, fraction of the drug } \\
\text { tion; } R^{2} \text { adjusted, adj } \\
\text { diffusion release exp } \\
\text { non-Fickian diffusion; } \\
\mathrm{T}_{\mathrm{i}} \text { location paramete }\end{array}$ & $\begin{array}{l}\text { leased in time } t ; k \text {, release rate } \\
\text { ed coefficient of determination; } \\
\text { ent }(n \leq 0.43-\text { Fick diffusion; } 0 \\
\geq 0.85 \text { - zero order release); } \alpha \text {, } \\
5 \text { ]. }\end{array}$ & $\begin{array}{l}\text { constant; } \\
\text {; AlC, Aka } \\
43<\mathrm{n}< \\
\text { scale parc }\end{array}$ & $\begin{array}{l}2^{2}, \text { coefficien } \\
\text { e Informatic } \\
85 \text { - anome } \\
\text { neter; } \beta \text {, she }\end{array}$ & $\begin{array}{l}\text { of deterr } \\
\text { n Criteric } \\
\text { lous tran } \\
\text { pe param }\end{array}$ \\
\hline
\end{tabular}

In order to gain deeper insight into RSP release kinetics from investigated nanoemulsions, experimentally obtained release data were fitted into different mathematical models - zero order, first order, Higuchi, Hixson-Crowell, Baker-Lonsdale, Korsmeyer-Peppas, and Weibull $[35,36]$, and the parameters calculated are reported in Table 2. Based on the values of the coefficient of determination $\left(R^{2}\right)$, the adjusted coefficient of determination ( $R^{2}$ adjusted), and Akaike Information Criterion (AIC) $[35,36]$, the best fitting of the experimental data were obtained with the Korsmeyer-Peppas model and Weibull model (the highest $\mathrm{R}^{2}$ and $\mathrm{R}^{2}$ adjusted, the lowest AIC, Table 2). However, considering that the Weibull model is empiric, without any kinetic basis, that could only de- scribe but not adequately characterize the release properties of the drug [35,36], the Korsmeyer-Peppas model was chosen as optimal to interpret the release kinetics of RSP from investigated parenteral nanoemulsions.

By analyzing the release rate constant of RSP from the two tested nanoemulsions (Table 2, KorsmeyerPeppas model), it could be noticed that the release rate of RSP was significantly higher ( $t$-test, $p<0.001)$ from nanoemulsion stabilized by lecithin and co-stabilized with polysorbate 80 (RSP-IpNE) than from nanoemulsion stabilized by lecithin alone (RSP-INE). The possible explanation for a greater release rate and a greater release extent as well (within the first hour, as discussed above) of RSP from nanoemulsion containing polysorbate 80 (RSP-IpNE) might be a smaller droplet size of this nanoemulsion compared to the co-emulsifier-free formulation (RSP-INE), resulting in the increased surface area available for the drug transport from the donor to the receiver phase. Furthermore, in the case of RSP-IpNE nanoemulsion, a larger portion of RSP might be solubilized in the micelles/vesicles, most likely presented in the aqueous phase, from which drug molecules are expected to be readily accessible for a rapid release/transport; however, this assumption should be further addressed through drug distribution studies. Based on the value of diffusion release exponent ( $n$ ), figuring out in the Korsmeyer-Peppas model and indicating the release mechanism of the drug $[35,36]$, it could be suggested that the release of RSP from two investigated nanoemulsions was mainly diffusion-controlled ( $\leq \leq 0.43$, Table 2$)$.

\section{Conclusion}

In order to characterize the drug release kinetics/pattern from the nanoemulsion carrier, a case study where RSP, a poorly water-soluble antipsychotic drug, was incorporated into two lecithin-based parenteral nanoemulsions prepared by hot high-pressure homogenization and thoroughly examined in terms of physicochemical properties and biopharmaceutical performances was carried out.

Formulated RSP-loaded nanoemulsions, differing only in the presence of polysorbate 80 as co-emulsifier/ co-stabilizer, revealed a small mean droplet size, narrow size distribution, high surface charge, and low viscosity (RSP-IpNE: Z-Ave $160 \pm 2 \mathrm{~nm}$, PDI $0.13 \pm 0.02$, ZP -52 $\pm 2 \mathrm{mV}$, apparent viscosity $6 \pm 1 \mathrm{mPa}$.s; RSP-INE: Z-Ave $208 \pm 2 \mathrm{~nm}$, PDI $0.1 \pm 0.01$, ZP $-60 \pm 1 \mathrm{mV}$, apparent viscosity $4 \pm 1 \mathrm{mPa} . \mathrm{s}$ ), thus indicating their suitability for parenteral administration and a delivery of poorly watersoluble drugs. In vitro drug release study, conducted by employing a reverse dialysis bag technique showed biphasic release profiles of RSP from both tested nanoemulsions with above $95 \%$ of RSP released within $180 \mathrm{~min}$. Although significant differences could be observed in the release profiles of RSP from two investigated nanoemulsions, indicating the influence of nanoemulsion matrix on the drug release kinetics generally, it could be reported 
that the release of RSP from nanoemulsions was relatively rapid (more than $50 \%$ released within the first 5 $\min$ ) and that the initial differences in the released fraction of RSP disappeared with time (after $60 \mathrm{~min}$ ). Based on mathematical modeling of the release data, the kinetic release process of RSP from presented nanoemulsions could be described by Korsmeyer-Peppas model, and is supposed to be diffusion-controlled.

Regarding the overall results, a reverse dialysis bag technique could be considered to be a suitable method for evaluating the in vitro drug release from nanoemulsion systems which could distinguish between different nanoemulsion formulations, at least in our sample series.

To underline, the understanding of in vitro drug release, and testing thereof, is an essential task during the new drug development, the establishment of in vitro-in vivo correlation, registration and quality control of drugloaded parenteral nanoemulsions and nano-sized dosage forms in general. The drug release rate/pattern from the nanoemulsion system may be influenced by a range of factors including: (i) the drug properties (solubility, $\mathrm{pKa}$, partition coefficient), (ii) the carrier properties (internal morphology, droplet size and size distribution, surface/ interfacial properties), (iii) the release test conditions (release medium - volume, composition, and $\mathrm{pH}$; dialysis membrane; temperature; agitation), and (iv) the interplay between these variables. The listed factors should be considered and controlled when designing/choosing the adequate the in vitro release testing method for a nanoemulsion system, with the ultimate goal to ensure the quality, safety and efficacy of the drug product.

\section{Acknowledgments}

This work was supported by the Ministry of Education, Science and Technological Development, Republic of Serbia, within the framework of the Financing program for scientific research, ev. no. 451-03-68/202014/200133. The authors would like to thank Zdravlje Actavis for supplying RSP and to Lipoid $\mathrm{GmbH}$ for gifting Lipoid Purified Soybean Oil 700, Lipoid S 75, and Lipoid Sodium Oleate B.

\section{References}

[1] Y. Singh, J. G. Meher, K. Raval, F. A. Khan, M. Chaurasia, N. K. Jain, M. K. Chourasia, Nanoemulsion: Concepts, development and applications in drug delivery, Journal of Controlled Release 252 (2017) 28 - 49.

[2] K. Hörmann, A. Zimmer, Drug delivery and drug targeting with parenteral lipid nanoemulsions - A review, Journal of Controlled Release, 223 (2016) 85 - 98.

[3] P. P. Constantinides, M. V. Chaubal, R. Shorr, Advances in lipid nanodispersions for parenteral drug delivery and targeting, Advanced Drug Delivery Reviews, 60(6) (2008) $757-767$.

[4] X. Li, L. Du, C. Wang, Y. Liu, X. Mei, Y. Jin, Highly efficient and lowly toxic docetaxel nanoemulsions for intravenous injection to animals, Pharmazie, 66(7) (2011) 479 - 483.
[5] L. Nothnagel, M. G. Wacker, How to measure release from nanosized carriers? European Journal of Pharmaceutical Sciences, 120 (2018) 199 - 211.

[6] J. Shen, D. J. Burgess, In vitro dissolution testing strategies for nanoparticulate drug delivery systems: recent developments and challenges, Drug Delivery and Translational Research, 3(5) (2013) 409 - 415.

[7] C. K. Brown, H. D. Friedel, A. R. Barker, L. F. Buhse, S. Keitel, T. L. Cecil, J. Kraemer, J. M. Morris, C. Reppas, M. P. Stickelmeyer, C. Yomota, V. P. Shah, FIP/AAPS joint workshop report: dissolution/in vitro release testing of novel/special dosage forms, AAPS PharmSciTech, 12(2) (2011) 782 - 794.

[8] V. P. Shah, J. DeMuth, D. G. Hunt, Performance test for parenteral dosage forms, Dissolution Technologies, 22(4) (2015) $16-21$.

[9] D. J. Burgess, D. J. Crommelin, A. S. Hussain, M. L. Chen, Assuring quality and performance of sustained and controlled release parenterals: EUFEPS workshop report, AAPS PharmSci/American Association of Pharmaceutical Scientists, 6(1) (2004) 100 - 111.

[10] S. Benita, M. Y. Levy, Submicron emulsions as colloidal drug carriers for intravenous administration: comprehensive physicochemical characterization, Journal of Pharmaceutical Sciences, 82(11) (1993) 1069 - 1079.

[11] N. Chidambaram, D. J. Burgess, A novel in vitro release method for submicron sized dispersed systems, AAPS PharmSci/American Association of Pharmaceutical Scientists, 1(3) (1999) 1 - 9.

[12] J. Shen, D. J. Burgess, Accelerated in-vitro release testing methods for extended-release parenteral dosage forms, Journal of Pharmacy and Pharmacology, 64(7) (2012) 986 $-996$.

[13] N. Ammoury, H. Fessi, J. P. Devissaguet, F. Puisieux, S. Benita, In vitro release kinetic pattern of indomethacin from poly(D,L-lactide) nanocapsules, Journal of Pharmaceutical Sciences, 79(9) (1990) 763 - 767.

[14] N. S. Santos-Magalhães, G. Cave, M. Seiller, S. Benita, The stability and in vitro release kinetics of a clofibride emulsion, International Journal of Pharmaceutics, 76(3) (1991) 225 - 237.

[15] P. F. Yue, X. Y. Lu, Z. Z. Zhang, H. L. Yuan, W. F. Zhu, Q. Zheng, M. Yang, The study on the entrapment efficiency and in vitro release of puerarin submicron emulsion, AAPS PharmSciTech, 10(2) (2009) 376 - 383.

[16] C. Washington, K. Evans, Release rate measurements of model hydrophobic solutes from submicron triglyceride emulsions, Journal of Controlled Release, 33 (1995) 383 -390 .

[17] J. M. Voisine, B. S. Zolnik, D. J. Burgess, In situ fiber optic method for long-term in vitro release testing of microspheres. International Journal of Pharmaceutics, 356(1-2) (2008) $206-211$.

[18] U. Bhardwaj, D. J. Burgess, A novel USP apparatus 4 based release testing method for dispersed systems, International Journal of Pharmaceutics, 388(1-2) (2010) $287-294$.

[19] A. Rawat, E. Stippler, V. P. Shah, D. J. Burgess, Validation of USP apparatus 4 method for microsphere in vitro release testing using Risperdal Consta, International Journal of Pharmaceutics, 420(2) (2011) 198 - 205.

[20] L. Salmela, C. Washington, A continuous flow method for estimation of drug release rates from emulsion formulations, International Journal of Pharmaceutics, 
472(1-2) (2014) $276-281$.

[21] J. M. Morais, D. J. Burgess, In vitro release testing methods for vitamin $\mathrm{E}$ nanoemulsions, International Journal of Pharmaceutics, 475(1-2) (2014) 393 - 400.

[22] W. P. Forrest, K. G. Reuter, V. Shah, I. Kazakevich, M. Heslinga, S. Dudhat, S. Patel, C. Neri, Y. Mao, USP Apparatus 4: a valuable in vitro tool to enable formulation development of long-acting parenteral (LAP) nanosuspension formulations of poorly water-soluble compounds, AAPS PharmSciTech, 19(1) (2018) 413 - 424.

[23] D. Friedman, S. Benita, A mathematical model for drug release from o/w emulsions: application to controlled release morphine emulsions, Drug Development and Industrial Pharmacy, 13(9-11) (1987) 2067 - 2085.

[24] M. Y. Levy, S. Benita, Drug release from submicronized o/w emulsion: a new in vitro kinetic evaluation model, International Journal of Pharmaceutics, 66(1-3) (1990) $29-37$.

[25] N. S. Santos-Magalhães, A. Pontes, V. M. Pereira, M. N. Caetano, Colloidal carriers for benzathine penicillin G: nanoemulsions and nanocapsules, International Journal of Pharmaceutics, 208(1-2) (2000) $71-80$.

[26] F. A. Araújo, R. G. Kelmann, B. V. Araújo, R. B. Finatto, H. F. Teixeira, L. S. Koester, Development and characterization of parenteral nanoemulsions containing thalidomide, European Journal of Pharmaceutical Sciences, 42(3) (2011) 238 - 245.

[27] X. Xu, M. A. Khan, D. J. Burgess, A two-stage reverse dialysis in vitro dissolution testing method for passive targeted liposomes, International Journal of Pharmaceutics, 426(1-2) (2012) 211 - 218.

[28] Y. Zambito, E. Pedreschi, G. Di Colo, Is dialysis a reliable method for studying drug release from nanoparticulate systems? - A case study, International Journal of Pharmaceutics, 434(1-2) (2012) 28 - 34.

[29] D. Marín-Quintero, F. Fernández-Campos, A. C. CalpenaCampmany, M. J. Montes-López, B. Clares-Naveros, A. Del Pozo-Carrascosa, Formulation design and optimization for the improvement of nystatin-loaded lipid intravenous emulsion, Journal of Pharmaceutical Sciences, 102(11) (2013) 4015 - 4023.

[30] S. M. Đorđević, A. Santrač, N. D. Cekić, B. D. Marković, B. Divović, T. M. Ilić, M. M. Savić, S. D. Savić, Parenteral nanoemulsions of risperidone for enhanced brain delivery in acute psychosis: Physicochemical and in vivo performances, International Journal of Pharmaceutics, 533(2) (2017) 421 - 430.

[31] S. M. Đorđević, N. D. Cekić, M. M. Savić, T. M. Isailović, D. V. Ranđelović, B. D. Marković, S. R. Savić, T. Timić Stamenić, R. Daniels, S. D. Savić, Parenteral nanoemulsions as promising carriers for brain delivery of risperidone: Design, characterization and in vivo pharmacokinetic evaluation, International Journal of Pharmaceutics, 493(1-2) (2015) 40 - 54.

[32] American Chemical Society, SciFinder - A CAS Solution, SciFinder - CAS Registry Number 106266-06-2, Available from: https://scifinder.cas.org/scifinder/view/scifinder/ scifinderExplore.jsf (last access 30.11.2019.).

[33] N. A. Kasim, M. Whitehouse, C. Ramachandran, M. Bermejo, H. Lennernäs, A. S. Hussain, H. E. Junginger, S. A. Stavchansky, K. K. Midha, V. P. Shah, G. L. Amidon, Molecular properties of WHO essential drugs and provisional biopharmaceutical classification, Molecular pharmaceutics, 1(1) (2004) 85 - 96.
[34] S. Đorđević, T. Isailović, N. Cekić, G. Vuleta, S. Savić, Parenteralne nanoemulzije diazepama: fizičko-hemijska karakterizacija i in vitro ispitivanje brzine oslobađanja, Arhiv za farmaciju, 66 (2016) 24 - 41.

[35] P. Costa, J. M. Sousa-Lobo, Modeling and comparison of dissolution profiles, European Journal of Pharmaceutical Sciences, 13(2) (2001) 123 - 133.

[36] S. Cascone, Modeling and comparison of release profiles: Effect of the dissolution method, European Journal of Pharmaceutical Sciences, 106 (2017) 352 - 361. 
Izvod

\section{METOD REVERZNE DIJALIZE SA VREĆICAMA ZA PROCENU IN VITRO OSLOBAĐANJA LEKOVITE SUPSTANCE IZ PARENTERALNIH NANOEMULZIJA - STUDIJA SA RISPERIDONOM}

Nebojša D. Cekić ${ }^{1,2}$, Sanela M. Savić ${ }^{\text {, Tanja M. Ilić }}$, Snežana D. Savić ${ }^{3}$

${ }^{1}$ DCP Hemigal, Leskovac, Srbija

${ }^{2}$ Tehnološki fakultet, Univerzitet u Nišu, Leskovac, Srbija

${ }^{3}$ Katedra za farmaceutsku tehnologiju i kozmetologiju, Farmaceutski fakultet, Univerzitet u Beogradu, Beograd, Srbija

Prikazana studija opisuje profil oslobađanja risperidona, u vodi slabo rastvorljive psihofarmakološke lekovite supstance, iz dve parenteralne nanoemulzije koje su sadržale smešu triglicerida srednje dužine lanca i sojinog ulja kao uljanu fazu, rastvor natrijum oleata kao vodenu fazu, i lecitin sam ili u kombinaciji sa polisorbatom 80 kao emulgatore/stabilizatore. Nanoemulzije su izrađene toplim postupkom homogenizacije pod visokim pritiskom i okarakterisane u pogledu fitičko-hemijskih svojstava - veličina kapi, indeks polidisperznosti, zeta potencijal, viskozitet, kao i biofarmaceutskih performansi - in vitro oslobađanje lekovite supstance, primenom tehnike reverzne dijalize sa vrećicama.Fizičko-hemijska karakterizacija je pokazala zadovoljavajuću prosečnu veličinu kapi (160-210 nm), usku raspodelu veličina $(<0,15)$, visoko površinsko naelektrisanje (oko $-50 \mathrm{mV}$ do $-60 \mathrm{mV}$ ), i nizak prividni viskozitet (4-6 mPa.s) razvijenih nanoemulzija, potvrđujući njihovu pogodnost za parenteralnu primenu u vodi slabo rastvorljivih aktivnih supstanci. In vitro ispitivanje brzine oslobađanja pokazalo je bifazne profile oslobađanja risperidona, sa određenim značajnim razlikama između ispitivanih formulacija nanoemulzija (koje su se razlikovale samo po prisustvu polisorbata 80), ukazujući na uticaj nanoemulzionog matriksa na kinetiku oslobađanja lekovite supstance. Pokazano je da je oslobađanje risperidona iz ispitivanih nanoemulzija bilo relativno brzo (više od $50 \%$ oslobođeno tokom prvih $5 \mathrm{~min}$ ), što dalje ukazuje na njihovu obećavajuću primenu u hitnim stanjima. Dodatno, preko 95\% risperidona oslobodilo se iz obe ispitivane nanoemulzije nakon 180 min, pri čemu se kinetika oslobađanja mogla opisati Korsmeyer-Peppas modelom, a proces oslobađanja je verovatno kontrolisan mehanizmom difuzije.Sveukupno posmatrano, može se zaključiti da je tehnika reverzne dijalize uz primenu vrećica bila pogodan i dovoljno diskriminatoran metod za procenu in vitro brzine oslobađanja risperidona iz prikazanih nanoemulzionih sistema.
(ORIGINALNI NAUČNI RAD)

UDK 615.214.2.015:66.09

Ključne reči: nanoemulzije, risperidon, ispitivanje brzine oslobađanja, dijalizni metod, profil oslobađanja, matematičko modelovanje 